\title{
Empirical Analysis of Tourism as a Tool to Increase Foreign Direct Investment in Developing Country: Evidence from Malaysia
}

\author{
Aftab Alam \\ College of Business Administration King Saud University Saudi Arabia \\ UniKI Business School (University of Kuala Lumpur) Malaysia \\ Omair Mujahid Malik \\ College of Business Administration King Saud University Saudi Arabia
}

Manzoor Ahmed

Department of Marketing College of Business Administration King Saud University Riyadh Saudi Arabia

Kamisan Gaadar

University of Kuala Lumpur Business School (Uni KI) Kuala Lumpur Malaysia

\section{Doi:10.5901/mjss.2015.v6n4s3p201}

\section{Abstract}

In this research manuscript studies to investigate the association between tourism and Foreign Direct Investment (FDI) in emerging countries by selecting Malaysia from amongst the developing countries. The connection among tourism and FDI growth has been argued whether tourism contributes to the growth of FDI or it is impacted by growth of the economies (economic-driven tourism development). This paper studies the impact of tourism on Foreign Direct Investment (FDI) growing in Malaysia. The purpose of this paper is to identify the key factors influencing foreign direct investment (FDI) in the Malaysia tourism business. This is done in order to effectively attract and withstand FDI as well as to remain economical.

\section{Introduction}

Tourism has develop one of the most important export sectors in many emerging countries. An over-all compromise has emerged that it not only the growths of foreign exchange income, but also generates employment openings, motivates the growth of the tourism business and by advantage of this, activates over-all financial development. Malaysia is a somewhat unexpected entry on the most visited list, especially compared with the usual tourist destination of Paris, London and New York. A visit to Malaysia is nearly corresponding to visiting two countries in one, as the point on which the country is located is divided by the South China Sea. One of its landmass features the fabled, but lessening, jungle of Borneo, whilst the western area is made up of plains and cultural mix of Malay, Chinese and Indian influences. Unlike some of the countries in the area, Malaysia relishes a stable political and economic setting and is making use of her funds to host her 25 million annual visitors. Beach, adventure, and safari holidays are all available, and for the less intrepid the country is the proud owner of a LEGOLAND and a hello kitty Theme park (the first outside of the other country). According Top 10 Tourist Destinations in 2012 Malaysia was on tenth position and twenty five million tourist visited to Malaysia, the famous tourists spot are Petronas (Twin Towers) in Kuala Lumpur, Eye on Malaysia / Ferris wheel in Kuala Lumpur, Kota Kinabalu in Sabah, Melaka in Malacca, Langkawi in Kedah, Sunway Lagoon in Petaling Jaya, Batu Caves in Kuala Lumpur, offering the beauty of world and true nature - Malaysia is unique and has a multi-cultural society to see and experience. An International world class Airport, Metro, road networks and latest infra-structure are the main sources to attract the worlds eyes, the innocent people and their humble and friendly behavior and soft manners in dealing with tourist is a source of attraction for foreign tourists. 


\section{Literature}

From past studies tourism and foreign direct investment the following studies have been carried out and published.

The aim of this studies is to relate the results of three isolated input-output studies carried out to measure and display the contribution of international tourism to the economy of Bermuda in judgment with the effects made by other export areas (Archer, B. 1995)

The purpose of this studies is to discover the empirical relation among foreign direct investment (FDI) in real estate sector and international tourism. Panel co-integration and panel Granger causality techniques are functional to analyze both long-and short term link with each other's (Fereidouni, H. G., \& Al-mulali, U. 2014)

The aim of this study is to observe the important link among foreign direct investment (FDI) and tourism in China. This clarifies the fast progress in the tourism marketplace in China during the past decade and attracted more tourist in China (Tang, S., Selvanathan, E. A., \& Selvanathan, S. 2007)

In this study we found the impact of tourism receipts, exports and foreign direct investment on economic growth on four ASIAN countries namely India, China, Pakistan and Russia. Tourism and export are play important role increase FDI (Tiwari, A. K. 2011)

Following a brief overview from this study of the recent growth of tourism in Hungary, describes foreign direct investment (FDI) projects implemented, or currently in developing, in the hotel, accommodation and catering sub-sectors of Hungarian tourism. Tourism is main source for FDI in Hungry (Behringer, Z., Kiss, K., \& Hall, D. R. 2004).

The purpose of this studies is examine foreign direct investment (FDI) in the term of tourism industry of Turkey and the relevance of international business theories in explaining that foreign investment tourism is played majors role (Buckley, P., \& Geyikdagi, N. V. 1996)

Tourism is a major income source in the world like in Vietnamese Government has embattled it for planned foreign direct investment (FDI). Notes although research scholars and strategy makers understand specific features of tourism, they often misperceive how the variables interrelate within economic and political systems. (Haley, U. C., \& Haley, G. T. 1997)

In this paper the authors tried to discuss Nation Branding dimension tourism is a tools for foreign direct investment (FDI) in Pakistan, and to find the interrelation between nation Branding dimension tourism and foreign direct invest in Pakistan (Alam, A., Almotairi, M., \& Gaadar, K. 2013)

Conclusion of this study proposes that there may be numerous details of ineffective relationship among imperceptible assets (tourism) of poorer countries and economic growing of the country, but brand theory proposes that lacking an influential stratagem for deploying a creative and harmonized way is the major cause. Tourism is played majors role in developing countries (Alam, A., Ullah, S., Ahmed, M., \& Gaadar, K. 2013)

Tourism is one of the greatest rising industries in the world. Many developing countries reflect it as opportunity for raising export incomes. Most significant part in the internationalization of production has foreign direct investment (FDI). This paper examines the influence of FDI (Foreign direct investment) on economic development (Ivanovo, Z., Baresa, S., \& Bogdan, S. 2011)

The aim of this study medium and long delay in a reasonable period, the increase in the size of inbound tourism can effectively promote FDI flows, they cannot form a feedback mechanism of interaction. Tourists scale changes on the FDI impact on the most significant changes for longer. The scale of FDI impact on inbound tourism value the most and widest amplitude, but the lag effect is not stable enough (Ming, G. A. O. 2011)

The main objective of this research is to examine the existing state of (FDI) in China and the influence in Tourism Sector in terms of flows, geographical distribution, employment, type and quality of services, etc. Furthermore, it will be attempted to estimate its effects on the domestic tourism industry and the national economy at large. (Broadman, H. G., \& Sun, X. 1997).

This research manuscript tries to determine the factors poignant foreign direct invest (FDI) in Tourism area, appraises the policies adopted to attract FDI, and examines the benefits of foreign direct invest (FDI) in the growth of Tourism sector. (Sharma, P. K., Jadhav, U. N., Singh, E. H., \& Mahapatra, A. 2012) 


\section{Research Frame Work}

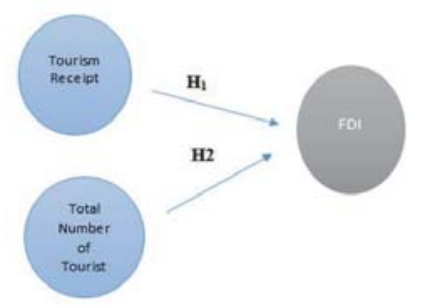

\section{Hypotheses}

$\mathrm{H}_{1}$ There is a relationship between tourism receipt and FDI

$\mathrm{H}_{2}$ There is a relationship between total number of tourist and FDI

\section{Objective}

To find out the relationship between tourism and FDI. What is the impact of tourism on FDI? The main objective of this work is to recommend the optimum ways in which Malaysia can improve tourism and brand itself as a country by considering the different factors that can be used to enhance its image and create a unique identity for itself among the nations of the world and to use this positioning as a source of attracting FDI in Malaysia.

\section{Data and Methodology}

This paper evaluates the relationship of Tourism and foreign direct investment (FDI). Is tourism playing any important role to increase foreign direct investment in Malaysia? The data are available from time period of 1995 to 2011, and it qualitative research secondary source of data are collected from World Bank data sources. From this 17 years data we will analyze and find out the results and its effects on FDI. FDI is tabulated in US dollars as well as total receipt from tourism and total numbers of tourist in millions. The update value for Foreign direct investment (FDI), net influxes (Bop, current US\$) in Malaysia was $\$ 12,000,760,000$ as of 2011 . Over the past 17 years, the value for this indicator has fluctuated between $\$ 12,000,760,000$ in 2011 and $\$ 4,178,239,000$ in 1995. In the year (996-1995) the difference in FD was 900176000.00 US\$, in the years (1997-1996) FDI difference was in US 58,100,000.00 \$. In the year (2011-201) the difference of FDI was in US $\$ 2,833,558,000.00$, the up-to-date value for International tourism, receipts (current US\$) in Malaysia was $\$ 19,593,000,000$ as of 2011 . Over the previous 16 years, the value for this pointer has diverse among $\$ 19,593,000,000$ in 2011 and $\$ 3,237,000,000$ in 1998. The value for International tourism, number of arrivals in Malaysia was $24,714,000$ as of 2011 . As the table under shows, over the past 16 years this indicator reached an all-out number of 24,714,000 in 2011 and a minimum number of 5,551,000 in 1998.

FDI, Receipt of Tourism and Total Numbers of Tourist (1995-2011)

\begin{tabular}{|c|c|c|c|}
\hline Year & FDI in US \$ & Total Receipt in US \$ & Total Number of Tourist \\
\hline 1995 & 4178239000 & 5044000000 & 7469000 \\
\hline 1996 & 5078415000 & 5732000000 & 7138000 \\
\hline 1997 & 5136515000 & 4925000000 & 6211000 \\
\hline 1998 & 2163402000 & 3237000000 & 5551000 \\
\hline 1999 & 3895263000 & 4403000000 & 7931000 \\
\hline 2000 & 3787632000 & 5873000000 & 10222000 \\
\hline 2001 & 553947400 & 7627000000 & 12775000 \\
\hline 2002 & 3203421000 & 8084000000 & 13292000 \\
\hline 2003 & 2473158000 & 6799000000 & 10577000 \\
\hline 2004 & 4624210000 & 91830000000 & 15703000 \\
\hline 2005 & 3924787000 & 10389000000 & 16431000 \\
\hline 2006 & 7690731000 & 12280000000 & 17547000 \\
\hline 2007 & 9071370000 & 17948000000 & 20973000 \\
\hline 2008 & 7572512000 & 18553000000 & 22052000 \\
\hline 2009 & 114664400 & 17231000000 & 23646000 \\
\hline 2010 & 9167202000 & 18315000000 & 24577000 \\
\hline 2011 & 12000760000 & 19593000000 & 24714000 \\
\hline
\end{tabular}

Source: http://www.indexmundi.com/facts/malaysia/foreign-direct-investment

Sources: http://www.indexmundi.com/facts/malaysia/international-tourism 
In methodology first we will find out correlation between total numbers of tourist, and total receipt and foreign direct investment (FDI), then we will find out the liner regression analysis to find out the relationship and its impact on foreign direct investment (FDI), Total number of tourist (IV) and total receipt (IV) are independent variable and foreign direct investment (FDI) is dependent variable.

\section{Empirical Results}

1- Model Summery of FDI, Total Number of Tourist and Total Receipt from Tourism

Model Summary

\begin{tabular}{|c|c|c|c|c|}
\hline Model & $\mathrm{R}$ & $\mathrm{R}$ Square & Adjusted R Square & Std. Error of the Estimate \\
\hline 1 & $.707^{\mathrm{a}}$ & .500 & .429 & 2410770278.117 \\
\hline
\end{tabular}

a. Predictors: (Constant), Total Number Tourist, Total Receipt (US\$)

From above table $\mathrm{R}^{2}=0.500=50 \%, 50 \%$ change of change in Foreign Direct Investment (FDI) explained by change in Total Number of Tourist and Total Receipt from Tourism, foreign direct invest (FDI) 50\% depend on Tourism revenue, its if tourism increase so FDI will increase

2- Anova Model of FDI, Total Number of Tourist and Total Receipt from Tourism

\begin{tabular}{|c|c|c|c|c|c|}
\hline \multicolumn{6}{|c|}{ ANOVA $^{a}$} \\
\hline Model & Sum of Squares & $d f$ & Mean Square & $\mathrm{F}$ & Sig. \\
\hline Regression & 81417407287524980000.000 & 2 & 40708703643762490000.000 & 7.004 & $.008^{b}$ \\
\hline 1Residual & 81365386673911330000.000 & 14 & 5811813333850809300.000 & & \\
\hline Total & 162782793961436300000.000 & 16 & & & \\
\hline
\end{tabular}

a. Dependent Variable: FDI_US\$

b. Predictors: (Constant), Total Number Tourist, Total Receipt US\$

From Anova model we conclude that the model is significant at $5 \%$ level

3- Coefficients of FDI, Total Number of Tourist and Total Receipt from Tourism

Coefficients

\begin{tabular}{|l|c|c|c|c|c|}
\hline \multirow{2}{*}{ Model } & \multicolumn{2}{|c|}{ Unstandardized Coefficients } & Standardized Coefficients & \multirow{2}{*}{$\mathrm{t}$} & \multirow{2}{*}{ Sig. } \\
\cline { 2 - 5 } & $\mathrm{B}$ & Std. Error & Beta & & \\
\hline (Constant) & 3469232496.629 & 1640599926.890 & & 2.115 & .053 \\
1Total Receipt US\$ & 1.172 & .468 & 2.128 & 2.506 & .025 \\
\hline Total Number Tourist & -728.188 & 399.205 & -1.549 & -1.824 & .090 \\
\hline
\end{tabular}

a. Dependent Variable: FDI_US\$

The table shows that there is a positive connection between Total Receipt US \$ and foreign direct investment (FDI) FDI as the $P$ value $(\beta=0.025)$ is significant at $5 \%$ level. From above table shows that there is a negative connection between Total Number of Tourist and foreign direct investment (FDI) as the $p$ value $(\beta=0.90)$ is significant at $10 \%$ level. Moreover the regression model of the relationship between Total Receipt from Tourism and Total Number of Tourist and FDI can be described as follows

$\mathrm{FDI}=\alpha_{0}+\beta_{1} \mathrm{X}_{1}+\beta_{2} \mathrm{X}_{2}$

$Y=3469232496.629+1.172 X_{1}-728.188 X_{2}$

Where y=Foreign Direct Investment (FDI)

$X_{1}=$ Total Receipt US\$)

$X_{2}=$ Total Number Tourist

The below graph:1 shows, there is direct relationship between Total Receipt from Tourism and FDI the positive relationship between Total Receipt from Tourism and FDI, if Total Receipt from Tourism increases than FDI will also increase and if Total Receipt from Tourism decrease FDI will decrease. The graph further shows us that 9 observations 
exist above the trend line in the high stage whereas 7 observations are occurring below the trend line on a lower stage while one is on the borderline. We can easily understand the implications this graph has suggesting that the government should take more active and positive steps to towards improving tourism. Which would in turn improve the overall balance of payment, economic conditions and thereby project an optimistic economy to the international world markets. Revenue from tourism has a positive effect on foreign direct investment FDI, furthermore revenue from tourism will improve the national economic conditions.

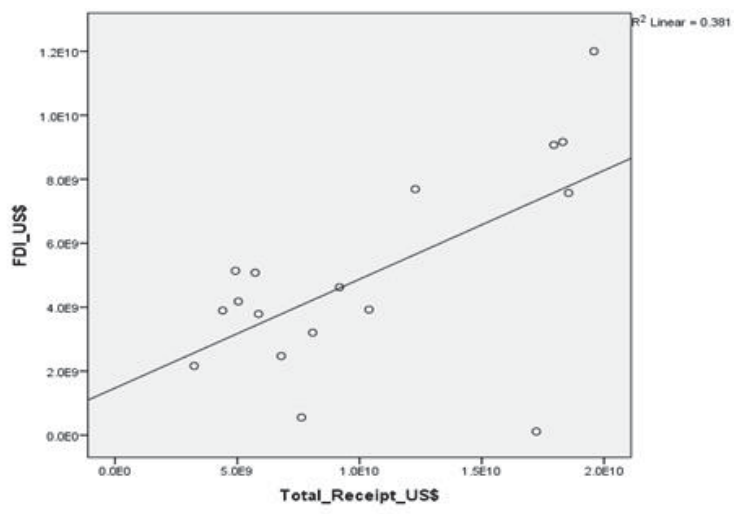

\section{Graph 1: FDI and Total Receipt from Tourism}

The below graph:2 shows, there is direct connection between Total number of tourist and foreign direct investment (FDI) the positive relationship between Total number of tourist and foreign direct investment (FDI), if total number of tourist from Tourism increases than FDI will also increase and if Total Receipt from Tourism decrease FDI will decrease. The graph further shows us that 9 observations exist above the trend line in the high stage whereas 6 observations are occurring below the trend line on a lower stage while one is on the borderline

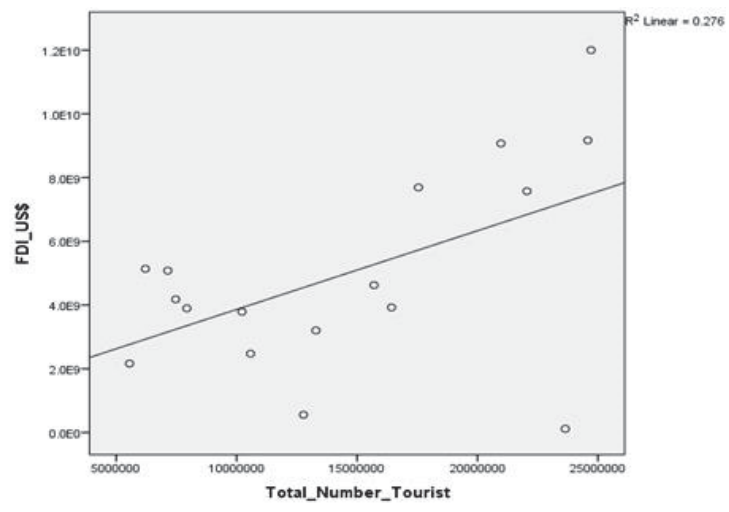

Graph 2: FDI and Total Receipt from Tourism Number of Tourist

\section{Finding and Conclusion}

From empirical analysis we found that total number of tourist and foreign direct investment is significant. Proving a positive direct relation with each other's, i.e. foreign direct investment and total numbers of tourist. When the number of tourist increase so it create more revenue for the country and effect on FDI. For total receipt from tourism is directly link and have positive effect with FDI. From regression analysis it's significant and its positive relation of total number of tourist and total revenue with foreign direct investment FDI, from graph observation it have strong relation with dependent 
variable and independent variable, The main purpose of this study is to examine the effect of worldwide tourism on the economic development and growth of (FDI)in Malaysia. The consequences show that the spending of international tourists positively impacts the economic development (FDI) in Malaysia. From Tourism is predictable to contribute round about $12.5 \%$ to gross domestic product (GDP) next year, development over the current influence of nearly $12 \%$, the Tourism and Culture. However, founded on the study of this paper, it is reasonable that tourism industry is contributing meaningfully to the Malaysian economy in terms of foreign direct investment (FDI) producing output, income, employment, and value-added. As Malaysia is aimed to be a developing nation by 2018, this industry has the probable to contribute significantly near to achieving the objective Foreign Direct Invest (FDI) in Malaysia.

\section{References}

Archer, B. (1995). Importance of tourism for the economy of Bermuda. Annals of Tourism Research, 22(4), 918-930.

Fereidouni, H. G., \& Al-mulali, U. (2014). The interaction between tourism and FDI in real estate in OECD countries. Current Issues in Tourism, 17(2), 105-113.

Tang, S., Selvanathan, E. A., \& Selvanathan, S. (2007). The relationship between foreign direct investment and tourism: empirical evidence from China. Tourism economics, 13(1), 25-39.

Tiwari, A. K. (2011). Tourism, Exports and FDI as a Means of Growth: Evidence from four ASIAN Countries. The Romanian Economic Journal, 14(40), 131-151.

Behringer, Z., Kiss, K., \& Hall, D. R. (2004). The role of foreign direct investment in the development of tourism in post-communist Hungary. Tourism and transition: Governance, transformation and development, 73-81.

Buckley, P., \& Geyikdagi, N. V. (1996). Explaining foreign direct investment in Turkey's tourism industry. Transnational Corporations, 5, 99-110.

Haley, U. C., \& Haley, G. T. (1997). When the tourists flew in: strategic implications of foreign direct investment in Vietnam's tourism industry. Management Decision, 35(8), 595-604.

Alam, A., Almotairi, M., \& Gaadar, K. (2013). Nation branding: An effective tool to enhance fore going direct investment (FDI) in Pakistan. Research Journal of International Studies, 25, 134-141.

Alam, A., Ullah, S., Ahmed, M., \& Gaadar, K. (2013). Nation Branding, Intellectual Property Rights and Economic Development Nexus: A Prescriptive Approach. International Review of Management and Business Research, 2(4), 1113.

Ivanovo, Z., Baresa, S., \& Bogdan, S. (2011). Influence of FDI on tourism in Crostia. UTMS Journal of Economics, 2(1), 21-28.

Ming, G. A. O. (2011). Scale of Inbound Tourism and FDI Dependence. In Tourism Forum (Vol. 1, p. 011).

Broadman, H. G., \& Sun, X. (1997). The distribution of foreign direct investment in China. The World Economy, 20(3), 339-361.

Sharma, P. K., Jadhav, U. N., Singh, E. H., \& Mahapatra, A. (2012). Foreign Direct Investment (FDI): An observation about tourism sector of Bhutan. 